\title{
Review of Re@ct: Social Change Art Technology Symposium, 6-8 November 2019, Dundee, Scotland
}

\author{
MARIA CHATZICHRISTODOULOU \\ Associate Dean Research \& Enterprise, Kingston University London
}

\section{ABSTRACT}

A review of the Re@ct: Social Change Art Technology symposium, which was part of the NEoN Digital Arts Festival in 2019.

The Re@ct symposium was part of the NEoN Digital Arts Festival 2019. The symposium, which took place over three full days in the Scottish city of Dundee, travelled to a different venue every day, while featuring and being framed by artistic activities that were also part of the NEoN festival and were also spread around the city. The aim of the symposium was to examine "how artists use digital systems to effect change within our social and political realities" (Symposium website). The symposium was chaired by three "home-grown" scholars: Professor Joseph DeLappe of Abertay University in Dundee, Professor Sarah Cook of the University of Glasgow but based in Dundee, and Dr. Laura Leuzzi of Duncan of Jordanstone College of Art \& Design, Dundee (now of Sapienza University, Rome).

Two things struck me immediately about the symposium: The first was its nomadic nature, which meant that attending the symposium entailed exploring the city of Dundee alongside the concepts and ideas presented and debated as part of Re@ct The symposium launched in the impressive new Victoria \& Albert Museum Dundee, Scotland's first design museum, which opened its doors to the public in September 2018 and is already one of the city's most important landmarks. The second day was split between two venues; West Church, a functioning church and community hub that hosts organizations ranging from a choir to a girls' brigade as well as regular exercise classes; and Chambers East, a historic event space at the site of Dundee's old Royal Exchange. The symposium closed at Steps Theatre, situated within Dundee's Central Library in the Wellgate shopping center. Delegates were also guided to attend interconnected events as part of NEoN festival, which were taking place in the Science Centre, GENERATORprojects, Steeple Church, The Bach Café and Nomas*Projects, among other venues, as well as in the same venues where the symposium was located and, of course, online. Moving through the city, happening upon fragments of the festival and symposium in different types of locations, from a world-class museum to a small local café, from a historically significant events venue to a functioning church that is a community landmark, created a sense of social embeddedness. NEoN and Re@ct may 
have featured artists and scholars of international reputation, but both events were very much situated within their local context. The city — and people — of Dundee were present in this set of activities, which unfolded around them - around the river, the small historic center, the independent art galleries and cafés, the empty shops in the fading shopping mall, the streets and squares and public spaces_-all of which felt part of this particular locale.

The second thing that struck me about Re@ct was the "applied" nature of the conversations that were had in the symposium. The majority of the presentations, as the title of the symposium suggested, sought to present, critique, and unpack works situated at the point where artistic vision meets everyday life, illustrating how digital arts can have a direct positive effect on people and communities: Steve Lambert's keynote "Pro Bono Mercenary for Justice Recruitment Session" actively set out to recruit artist-activists, relaying his own experiences of collaborating with advocacy organisations to suggest concrete ways delegates could put their skills to work in order to contribute to movements for justice, equality, and human rights; Amanda McDonald Crowley's keynote "Artists and Food Systems: Towards Sustainable Futures" was equally applied, presenting her curatorial work with artists to develop radically collaborative and participatory projects, where audiences are invited to rethink their relationship to public space and food systems; and artist Mahwish Chishty presented examples of her practice of camouflaging modern war machines with folk imagery, raising questions around politics and power. Though some of the presentations, such as Sean Cubitt's keynote "Ecocritical Media Arts and the War on Terra," were theoretical in nature and more abstract than others, this did not jar the overall applied concept of the event, but rather enriched it, resulting in deeper, more thoughtful, complex, and sophisticated exchanges.

Panels explored a range of issues, such as the activist video practices of the 1970s and 1980s (Mercedes Vincente, Adam Lockhart, Tony Dowmunt, Alicja Pawluczuk), disruptive interventions in cultural and political contexts (Francesca Franco, B.D. Owens, Jon Blackwood, Fernando Martín Velazco), feminist and queer strategies (Laura Leuzzi, Joanna Walsh, Virginia Crisp, Giulia Casalini), maker and playful tactics for social change (Janna Ahrndt, Ray LC, Fruzsina Pittner, Lulamile Mohapi), practices of surveillance and activist approaches to taking back control (Violeta Vojvodic Balaz, Dennis Delgado, Martin Zeillinger, Conor McGarrigle) and questions around the use of digital systems for the empowerment of individuals and communities (Pip Thornton, Tom Keene, Johanna Hoffman, Andy Best).

Some of the presentations which stood out for me were Tony Dowmunt's work on the London Community Video Archive (LCVA), which seamlessly linked activist video practices of the 1970 s and 1980s to ongoing community engagement initiatives that invite present-day audiences to reflect on lessons from history through their own, contemporary experiences; Jon Blackwood's talk on contemporary artists, digital strategies, and political action in North Macedonia, which presented radical examples of critical artistic interventions in the political context of Nikola Gruevki's right-wing, ultra-nationalist government (2006-16), by the artist duo OPA (Obsessive Possessive Aggression) and the digital guerrilla group Sviracinje; Joanna Walsh's performative lecture "A Woman Sitting In Front of a Screen," which considered "affective, domestic and gendered labour" (Walsh in NEoN Re@ct Symposium Speakers Bios and Abstracts, pp. 19-20) in a poetic manner that created a welcome stylistic rupture in the context of the symposium; Janna Ahrndt's talk "P@tching In: Stitching Together Tactical Media and Social Aesthetics as a Political Art Practice," which examined ways of engaging communities in civic action through 
her own Maktivist (Maker + activist) and Craftivist (Craft + activist) practice; Dennis Delgado's talk "Dark Databases: Facial Recognition and its "Failure to Enroll," which examined bias and flaws in current facial recognition technology that reflect "a continuation of racism and false discursive positioning" (see Delgado in NEoN Re@ct Symposium Speakers Bios and Abstracts, pp. 6-7); and Tom Keene's "Database (E)state" art-activist project that explores how databases are used by local governments to manage council-owned houses in the UK through his personal experience of mounting an activist campaign against the demolition of his and others' homes in the Cressingham Gardens Estate in South London.

The symposium opened with my own keynote address that discussed activist performance events that aim to raise awareness around social and political issues through ephemeral, affective actions that "gesture" dissent; and closed with Marisa Morán Jahn's performative keynote on the element of copper and its historic use in technological innovations such as tools, anti-bacterials, and digital networks, leading to a set of questions on the exertion of control over bodies and land.

The Re@ct symposium offered a packed program of intellectual and practical inquiry into the ways that artists respond to crises — both local and global, social and political_-looking to "engage an uncertain future" (see symposium website) through the creative and critical potential of digital art. It so happens that Re@ct was the last symposium I attended in real space before the new global crisis of the coronavirus. And as the future looks ever more uncertain, the need for us to Re@ct to crises individually and collectively, creatively and critically, through the means afforded to us by digital technologies, is ever more urgent. I hope the Re@ct symposium returns as part of future iterations of the NEoN festival as those critical debates and practical explorations on art and activism are needed, perhaps now more than ever.

\section{REFERENCES}

Call for Submissions - Social Change Art Technology. https://northeastofnorth.com/reactsymposium-call-out/ accessed September 16, 2020.

NEoN Re@ct Symposium Speakers: Bios and Abstracts. https://northeastofnorth.com/wpcontent/uploads/2019/09/NEoN-Re@ct-Social-Change-Art-Technology-Abstracts-FINAL-1.pdf accessed September 16, 2020.

\section{AUTHOR BIO}

Professor Maria Chatzichristodoulou is Associate Dean Research \& Enterprise at Kingston School of Art, Kingston University. Previously, she was Head of External Development and Enterprise at the School of Arts and Creative Industries, London South Bank University, where she led the Centre for Research in Digital Story-making, the Division of Creative Industries, and the ERDFfunded project "Accelerating the Creative Economy with Immersive Technologies." 